\title{
THE RELATIONSHIP OF SQUEEZE STRENGTH AND ARM EXPLOSION POWER TO THE ABILITY OF FOREHAND DRIVE IN TENNIS COURT
}

\author{
M. Sahib Saleh ${ }^{1 *}$ Nurkadri $^{2}$ \\ ${ }^{1}$ Universitas Negeri Makassar, Makasar, Indonesia \\ ${ }^{2}$ Universitas Negeri Medan, Medan, Indonesia \\ E-mail: m.sahib.saleh@unm.ac.id
}

\begin{abstract}
This study aims to determine the relationship between the strength of the squeeze of the hand and the explosive power of the arm on the ability of forehand drive in playing tennis. The study population was all students of the Faculty of Sport Science State University of Makassar with a sample of 40 people. The sampling technique used was purposive sampling. Based on data analysis, there was a significant correlation between hand squeeze strength and arm explosive power to the ability of forehand drive in the tennis playing field of the students of the Faculty of Sport Sciences State University of Makassar. (1) There is a significant correlation between the strength of the hand squeeze and the ability of forehand drive in the tennis playing field of the students of the Faculty of Sport Science, State University of Makassar; (2) There is a significant correlation between arm explosive power and forehand drive ability in tennis playing field for students of the Faculty of Sport Science, Makassar State University; and (3) There is a significant relationship between the strength of the hand squeeze and the explosive power of the arm to the ability of forehand drive in tennis playing field for the students of the Faculty of Sport Science, State University of Makassar.
\end{abstract}

\section{Keywords: Squeeze Hands, Arms, Forehand Drive}

\section{Introduction}

Motion skills are the ability to make movements efficiently and effectively. Motion'skills areEan expression of the quality of coordination and control over the body parts involved in movement. The term motor skills has a more specific meaning in sports activities. Godfrey and Kephart (1969) put forward motion skills as follows: " Motor skill is a motor activity limited in extent and involves a single movement or a limited group of movements which are performance with high degrees of protection and accuracy. "Motion skills are defined as limited motion in space and the influence of a single or series of movements, in their appearance with a high degree of precision and precision. So the more complex the pattern of motion that must be done, the more complex the coordination and control of the body that must be done and this means that it is also more difficult to do. Motion skills are obtained through a learning process that is by understanding movements and making repetitive movements accompanied by an awareness of the mind of whether or not the motion has been carried out.

Achievement of forehand drive in a good game of tennis can be achieved with the existence of good physical abilities. Understanding physical abilities in

PJKR_

http://jurnal.unimed.ac.id/2012/index.php/jpehr 
sports are all physical abilities that determine the achievement of realization through personal ability. With physical abilities, of course, consist of physical elements whose roles vary from one branch to another, so also the basic techniques in one branch of sport must be different. The physical component of an athlete plays a very important role in his training program. The training program must be well planned and systematic and aimed at improving the physical fitness and functional abilities of the body system so as to enable athletes to achieve better performance, Marrow (1997).

Another factor that can help in forehand drive capability is the explosive power of the arm. The explosive power of each person's arm will be different, and the stronger and faster a person's muscles, the higher the work activities that can be carried out, and can obtain maximum work results in accordance with the objectives to be achieved. Like wise in doing forehand drive, the stronger and faster the arm of a tennis player, the forehand he has can kill the steps. This research discusses the relationship between arm explosive power and hand wringing strength on the ability of forehand drive in playing tennis.

The basic principle in playing tennis is to hit the ball over the net and enter the opponent's playing field. In hitting the ball, efforts will be made to make it difficult for the opponent to return it, so that the opponent blows off the field or engages on the net. Thus will get the value of the blow done. Every mistake in making a blow, resulting in the acquisition of those who did not make a mistake.

Analysis of the movement of the forehand drive in playing tennis shows that the racket is an extension of the player's arm, which is connected by grip. Grips for each player greatly affect the movements that occur on the racket as a tool of playing tennis. Besides that, the movement of hitting the ball from the grip (grip) needs to require pressure to achieve maximum forehand results. Hands and arms are a unity that must not be separated in playing tennis. The hand functions as a grip on the racket while the arm functions in swinging the punch.

Field tennis game is a series of movements and moves by the body in moving a ball alternately: with others. Game that uses tools or rackets by moving the ball in turn. This game can be played by two people called singles and four people called doubles, both women and men, from children to adults Husni (1990). The game of basic tennis is focused only on how to hit the ball with the racket and swing the racket, this is inseparable from the method of playing approach to support the basic techniques that are good and right in the game of tennis, Nurkadri (2019).

Field tennis is not just hitting the ball so that it can cross the net or net and dropping the ball within the playing field of tennis court, but to make a stroke or blow on a ball coming or reflecting a ball launched in a game. Husni, et al (1990) said several things that need to be considered as a basis in playing tennis, as follows: (1) concentration, especially in the hands and eyes, (2) how to hold the racket, (3) swing the racket, (4) motion feet, (5) moving the body, and (6) using taste.

PJKR_

http://jurnal.unimed.ac.id/2012/index.php/jpehr 
Basic techniques which must be mastered first before studying the punch forehand drive that grip or squeeze the hand (grip): (1) Easten grip: The handle or squeeze the hand is better to express and be able to play with balls of tall nor short. To determine this eastern grip method, in Sportive magazine (1991) it is described as follows: (1) hold the racket on the neck with the left hand and right hand for the left-handed player, (2) place the palm used behind the grip of the fingers attached. encircle the grip of the racket, (3) its position as if shaking hands with the racket and give the solidity of the hand to the racket, and (4) maintain that the grip of the hand grip with the racket does not waver during a blow, (2) Continental grip: Continental grip or continental hand made popular by the player Pancho Gonzales.

Grip or squeeze hands continental, described by Magethi (1990) as follows: (1) hold the racket with the left hand (the hand that did not used to play), (2) place the palms like the letter " $\mathrm{V}$ " between the thumb and forefinger on top racket, then fold your fingers tightly around the racket, and (3) maintain the hand squeeze position so that it stays firm in every stroke. (3) The handle or squeeze the hands of western: The handle or penggaman western developed on hard courts in California where the players cope with high balls by using a spin. Since then, the Western hand press has continued to grow.

Strengths and weaknesses of this hand squeeze, in sportsmanship magazine (1991), the strengths of western hand squeeze are stated, among others: (1) makes it easy for players to hit the ball with a top-spin, and (2) it is good to do the forehand attack and punch fast and balls of any shape and different heights. While the weakness wring hands westerns, among others: (1) it is difficult to overcome the balls flat, low and balls wide, because the position of the wrist leads to the floor or into, (2) game that uses wring hands of western difficulty making a stroke backhand in fast because the field of racket is only gne side only, and (3) in the game less agile and difficult when in front of the net, even though the punch and the forehand is hard.

Muscle strength is needed in doing movements such as: pulling, throwing, rejecting, pushing and lifting. These movements arise due to the contraction of muscles lengthening, shortening, moving away, approaching body parts, and circular movements in all directions in a $360^{\circ}$ angular range, Hardiyono \& Nurkadri (2018). A forehand is carried out with a firm hand from the position of the body, and several things that need to be considered in a forehand stroke: (1) Ready position, (2) Back-swing racket, (3) Hitting motion.

One component that must be possessed by a tennis player is strength, strength is the driving force of every physical activity. Harsono (1988) argues that: "Strength is the ability of muscles to generate tension in a prisoner. Muscle strength is the ability to develop maximum energy in maximum contractions to overcome resistance or load. Strength is very important in supporting the playing of tennis, especially forehan drive The reason why strength is very important is because: (1) because strength is the driving force of every sporting activity, (2) because strength plays an important role in protecting players / people from 
possible injury, and (3) because the strength of the player will be able to run more efficient, hit harder, so can the stability of the joints, Harsono (1988).

Type of power according to Bompa (1983) classifies as follows: (1) general strength (general strength), (2) specific strength (special powers), (3) maximum strength (maximum strength), (4) muscular strength (muscle strength), (5) power (explosive power), (6) absolute strength (absolute strength), and (7) relative strength (relative strength).

Explosive power is also known as explosive power which is very needed in various sports. Fox, Razak (1993) argues that: "Explosive power is the ability of a person to display maximum work per unit of time. There fore explosive power is expressed as work done per unit of time, so there is a functional relationship between energy power and work. "

The explosive power that is developed in the field of sports in the field of tennis, especially forehand drive, is the ability of the arm to do hard or maximal strokes, so that it does not only hit with full force but quickly. Thus it can be said that explosive power is the ability of muscles to exert maximum strength in a fast time. The combination of strength and speed, then the ability to create explosive power or power that is done quickly or strongly.

\section{Method}

This research was classified as a descriptive correlational study. The population in this study were all students of the Faculty of Sport Science State University of Makassar. The sample used was male students of the Faculty of Sport Science, State University of Makassar who had programmed and passed 40 tennis courses using purposive sampling techniques.

As follows: (1) Hand squeeze strength test using a hand grip dynamometer test; (2) Arm power test using medicine ball put test; (3) Test forehand drive ability in playing tennis. The collected data was analyzed statistically, processed through a computer in the SPSS version 12.00 program with a significant level of $95 \%$ or $\alpha$ : 0.05 , with the requirements analysis test using the KolmogorovSimirnov Test.

\section{Discussion}

\section{Correlation of Squeeze Strength on Forehand Drive Ability in Tennis Court Games}

The results of the correlation analysis test the strength of the hand squeeze on the ability of the forehand drive in the tennis playing field of the students of the Faculty of Sport Science, State University of Makassar. Correlation value is obtained $\left(r_{0}\right) 0.577$ with a probability level $(0,000)<\alpha 0.05$, while for the t test to test the significance of constants and dependent variables (squeeze strength). The $t_{\text {calculated }}$ value of 2,100 is seen in the attachment of the Sig / significance column of 0.043 , or the probability is far below $\alpha 0.05$ then $\mathrm{H}_{\mathrm{O}}$ is rejected and $\mathrm{H}_{1}$ is accepted. Thus there is a significant correlation between the strength of the hand squeeze on the ability of the forehand drive in the tennis 
playing field of the students of the Faculty of Sport Science, State University of Makassar.

Strength is the basis of all existing physical components, as stated by Halim (2004) that: "strength is the ability of a person to use his muscles to take the burden while working."

The basic technique that must be mastered before learning the forehand drive is grip or hand grip. The hand functions to be able to hold the racket, the racket is an extension of the players arm, which is connected by grip. The racket works well when the hands have good physical abilities. Therefore, the strength of each player's hand squeeze will be very helpful in playing field tennis. On the other hand, if the strength of the squeezed hand is not good or bad, the result of a punch in playing tennis is not optimal.

The performance of the muscles in the hand will greatly affect the forehand drive because if when making a forehand, the grip is less strong then the result of the blow is less than optimal or not directed. The way to hold the racket governs how to play. Therefore, the hand that is used as a racket grip needs to have muscle strength. In the game of tennis, the technique in grip or grip is divided into several ways, namely: (1) Easten grip, (2) Continental grip, and (3) Weasten grip. The three grip techniques are adjusted to the abilities possessed by the player. However, all forms of grip techniques can all be carried out when the hand has the physical ability of the hand squeeze strength. Physical fitness related to health which contains various forms of motion exercises and forms of cardiorespiratory endurance, muscle strength and endurance and flexibility, Nurkadri, Valianto, \& Novita (2019)

Correlation of Explosive Arm Power to the Ability of Forehand Drive in a Tennis Court

The results of the analysis of the correlation test of the explosive power of the arm to the ability of forehand drive in the tennis game of the students of the Faculty of Sport Science, Makassar State University Correlation values obtained ( $\left.\mathrm{r}_{0}\right) 0.520$ with a probability level $(0,000)<\alpha 0.05$, while for the $\mathrm{t}$ test to test the significance of constants and dependent variables (arm explosive power). The value of $t_{\text {arithmetic }}$ obtained 3.922 is seen in the attachment column Sig / significance is 0,000 , or the probability is far below $\alpha 0.05$ then $\mathrm{H}_{\mathrm{O}}$ is rejected and $\mathrm{H}_{1}$ is accepted. Thus there is a significant relationship of arm explosive power to the ability of forehand drive in the tennis game of the students of the Faculty of Sport Science, State University of Makassar.

The ability of a tennis player in a game is to aim a punch strongly and quickly using a racket. The main goal in achieving a forehand drive is to keep the opponent from returning the blow and to always kill the opponent's movements.

The hitting motion on a tennis court game is the body rotated sideways according to holding the racket according to the direction the ball is coming. The racket is swung back (back-swing) with a shoulder-high frame. The opposite leg

PJKR

http://jurnal.unimed.ac.id/2012/index.php/jpehr 
with the hand that swings the racket backward, is moved forward towards the net pointing at the area where the ball will be hit, Mangundap (1993).

Therefore, the arm in conducting forehand drive needs to be supported by the physical condition of the explosive power. Explosive power is a combination of two physical components, namely strength and speed, the intention is the ability to direct maximum energy in a short time. Fox, Razak (1993) argues that: "Explosive power is the ability of a person to display maximum work per unit of time. An important element in explosive power is muscle strength and muscle speed in exerting maximum power to overcome resistance, so that it can be concluded the limit of explosive power is the ability of muscles to exert maximum strength in a very fast time.

Muscle performance in performing a racket swing and when making a shot when the ball is bouncy will get stronger and faster strokes. The ability of a swing racket from behind (bakc-swing) is a square to do the results of a blow that will be directed at the desire of a player. There fore the arm's explosive power will greatly help a player when making maximum forehand blows.

The Relationship of Squeeze Strength and Arm Explosion Power to Forehand Drive Ability in Tennis Court Games

Based on test results data regression analysis wring arm strength and explosive power arm on the ability forehand drive on the game of tennis courts at students of the Faculty of Sport Sciences, State University of Makassar obtained pattern of relationships between the variables studied expressed by multiple regression equation $\mathbf{y}=0,316+0,328 \mathrm{X}_{1}+0.319 \mathrm{X}_{2}$. This equation provides information that if there is an increase or improvement in the strength of the hand wringing and the explosive power of the arm it can cause changes or increase the ability of forehand drive in tennis. The results of this analysis also obtained a regression value (Ro) of 0.590 with a probability level $(0,000)<\alpha 0.05$, for an $R$ Square value (coefficient of determination) 0.348 . This means that $34.8 \%$ of the forehand drive ability in playing tennis is explained by the strength of the hand squeeze and the explosive power of the arm. While the rest $(100 \%-34.8 \%=$ $65.2 \%$ ) is explained by other causes. From the Anova test or the F test, the F count was 9,879 with a significance level of 0,000 . Because the probability $(0,000)$ is much smaller than $\alpha 0.05$, the regression model can be used to predict the ability of forehand drive in playing tennis (can be applied to the population where the sample is taken). As for the t test to test the significance of constants and dependent variables (the ability of forehand drives in tennis court games). $\mathrm{T}_{\text {count }}$ obtained 3,304 shown in the attachment column Sig / significance is 0,000 , or probability far below $\alpha 0.05$. Then $H_{O}$ is rejected and $H_{1}$ is accepted or the regression coefficient is significant. Thus there is a significant relationship between the strength of the hand squeeze and the explosive power of the arm for the ability to forehand drive in the tennis game of the students of the Faculty of Sport Science, State University of Makassar.

PJKR_

http://jurnal.unimed.ac.id/2012/index.php/jpehr 
Forehand drive in a tennis game is hitting the ball with the front of the racket from the outside of the side of the body towards the inside. In the stroke movement, there are two things that need to be considered, namely; how to hold the racket and how to hit the ball with a forehand. The two things can not be separated in making punches, because one unit that is owned in the upper body structure, namely the hands and arms. The performance of the two elements will greatly influence the forehand. Both elements of the body structure need to be supported by physical conditions, namely the hands need the physical ability of strength and the arm is supported by the physical ability of explosive power.

The strength of the hand squeeze will help in griping the racket so that the racket does not easily come loose and facilitate ball control in hitting and anticipating the arrival of the ball. Strong hands will be very helpful in grip (grip) in the game of tennis. Besides that, in the game of tennis there are three ways to hold the racket technique, certainly not all of them are able to hold the racket properly if the hands they have are less than their physical abilities. Iskandar (2004) says that: "The way the grip of a racket can dictate the playing method." The movement of the racket will be better directed if the grip possessed by the tennis player is supported by the physical ability of the squeeze strength. There fore the strength of the hand wring will help in gripping on a racket which is used as a hitting tool in playing tennis.

Thus the squeeze strength and explosive power of a tennis player's arm will be very helpful in forehand drives in playing tennis. The combination of how to hold with the support of the physical ability of strength and when performing blows with the support of explosive power of the arm will provide the accuracy of a forehand drive.

\section{Conclusion}

After conducting the research, the following conclusions are made: (1) There is a significant correlation between the strength of the hand squeeze and the ability of forehand drive in the tennis playing field of the students of the Faculty of Sport Science, State University of Makassar; (2) There is a significant correlation between arm explosive power and forehand drive ability in tennis playing field for students of the Faculty of Sport Science, Makassar State University; and (3) There is a significant relationship between the strength of the hand squeeze and the explosive power of the arm to the ability of forehand drive in tennis playing field for the students of the Faculty of Sport Science, State University of Makassar.

\section{References}

Bompa, O. Tudor, 1983. Theory and Methodology of Training, Dubuque. Iowa: Kendall/Hunt Publising Company.

Godfrey dan Kephart, 1969. Movement Pattern and Movement Education. New York: Pleton-Century Hall Inc.

PJKR_

http://jurnal.unimed.ac.id/2012/index.php/jpehr 
Halim, Nur Ichsan, 2004. Tes Pengukuran Kesegaran Jasmani. Makassar: State University of Makassar City.

Nurkadri, M, 2019. Goenrich Basic Technique Model With Playing Approach For a Beginner Tennis Player. Proceedings of the 2nd Yogyakarta International Seminar on Health, Physical Education, and Sport Science (YISHPESS 2018) and 1st Conference on Interdisciplinary Approach in Sports (CoIS 2018). https;//doi.org/10.2991/yishpess-cois-18.2018.24.

Nurkadri, Valianto. B., \& Novita, 2019) Efectivenes of Physical Fitness Model With Game Approach in Improving Physical Fitness of Student at Gaja Mada Elemantary School in Medan. Journal of Physics: Comperence Series. https;//doi.org/10.1088/1742-6596/1387/1/012215.

Harsono, 1988. Coaching dan Aspek-Aspek Psikologi dalam Coaching. Jakarta: Departemen Pendidikan dan Kebudayaan Direktorat Jenderal Pendidikan Tinggi.

Hardiyono, B., \& Nurkadri, N, 2018. Efektifitas Model Latihan Keseimbangan Badan Dan Model Latihan Keseimbangan Konvensional Terhadap Hasil Pemanjatan Pada Olahraga Panjat Dinding Untuk Pemanjat Pemula. Jurnal Prestasi. $\quad$ Volume: 2, / Edisi: 3: https://doi.org/10.24114/jp.v2i3.10131

Husni, Agusta, dkk, 1990. Buku Pintar Olahraga. Jakarta: Mawar Gempita.

Iskandar, Cristian, 2004. 101 Tips Terpenting Tenis. Jakarta: Dian Rakyat.

Magethi, 1990. Permainan Tenis Lapangan. Jakarta: Batara Karya Aksara.

Mangundap Alex, 1993. Pedoman Singkat Permainan Tennis. Ujung Pandang: FPOK IKIP Ujung Pandang.

Marrow, Lucas, 1997. Pembinaan Kondisi Fisik. Ujung Pandang: FPOK IKIP Ujung Pandang.

Razak, Abraham, 1993. Perbandingan Pengaruh Latihan Plyometrik dengan Latihan Kecepatan dan Kekuatan terhadap Daya Ledak. Surabaya: Tesis PPs Airlangga.

Sportif Majalah Tim, 1991. Cara Menggenggam Raket Tennis. Jakarta: Majalah Sportif No. 193.

PJKR

http://jurnal.unimed.ac.id/2012/index.php/jpehr 